\title{
Purchase Intention of Korean Beauty Products among Undergraduate Students
}

\author{
Chui-Seong Lim (Corresponding author) \\ Faculty of Business, Economics and Accounting and Economic \\ HELP University, 50490 Kuala Lumpur, Malaysia \\ Tel: 60-3-2716-2000Ｅ-mail: chuiseong.lim@help.edu.my \\ Jia-Leng Loo \\ Faculty of Business, Economics and Accounting and Economic \\ HELP University, 50490 Kuala Lumpur, Malaysia
}

Tel: 60-3-2716-2000Ｅ-mail: leng1306@gmail.com

\begin{abstract}
Siew-Chin Wong
Faculty of Business, Economics and Accounting and Economic

HELP University, 50490 Kuala Lumpur, Malaysia

Tel: 60-3-2716-2000 Ext: 2130 E-mail: sc.wong@help.edu.my

Kay-Tze Hong

Faculty of Business and Law, School of Management and Marketing

Taylor University, 47500 Subang Jaya, Selangor

Tel: 60-3-5629-5672 E-mail: kaytze.hong@taylors.edu.my
\end{abstract}

Received: April 6, $2020 \quad$ Accepted: June 16, $2020 \quad$ Published: July 1, 2020

doi:10.5296/jmr.v12i3.17149 URL: https://doi.org/10.5296/jmr.v12i3.17149

\begin{abstract}
As one of the most growing sector, the market size of cosmetics in the Asia Pacific region and was forecasted to reach around USD 126.86 billion by 2020 , accounting for $32 \%$ of sales
\end{abstract}




\section{Macrothink}

Journal of Management Research

ISSN 1941-899X 2020, Vol. 12, No. 3

worldwide (Statista 2019). The prestige cosmetics segment in Malaysia has reached USD 198 million in 2019 with expected yearly growth of 5\% (Statista 2019). The influence of K-Pop and K-Drama have stimulated interests towards Korean products, especially Korean beauty products which is very popular amongst the young consumers. The purpose of present study is to investigate the influence of value factors on purchase intention among undergraduates. The study grounding on Theory of Consumption Value (TCV) of Functional Value, Social Value and Epistemic Value is to examine undergraduates purchase intention towards Korean beauty products. A sample of 351 undergraduates who aged between 18 to 26 responded to the study. Data analysis using SmartPLS reveals that Functional Value, Social Value and Epistemic Value are significant predictors of Korean beauty products purchase intention in Klang Valley Malaysia. Importance and Performance Matrix (IPMA) analysis reveals that social values having the importance performance and with more room for improvement as compared to the functional and epistemic values. This study contributes to both marketing literature and practical perspective in Korean beauty products purchase behaviors.

Keywords: Theory of Consumption Value (TCV); Korean beauty product; values; purchase intention 


\section{Introduction}

In today's society, physical attractiveness and beauty are continuously enhanced as admirable and desirable characteristics. Beauty products are used daily by every level of society, and their consumption is growing every year. It has become a necessity product in daily life for enhancing attractiveness, personal hygiene, skin protection and slowing down the aging process (Mitsui, 1996). Beauty products became a broad and popular category for young and adult consumers which it identified them with a more relaxed lifestyle and better versatility and comfort (Eze, Tan \& Yeo, 2012). Grateful to advancement in technology, people have greater purchasing power due to the fact that more people are getting more conscious towards product function and quality, such as hygiene, beauty and effectiveness (Souiden \& Diagne, 2009). It affects the beauty industry in growing innovative product, making them highly available, affordable and safe for consumption (Lockley \& Barsley, 2000).

The market size of cosmetics in the Asia Pacific region from 2015 to 2020 is amounted to about USD 98.5 billion in 2015 and was forecasted to reach around USD 126.86 billion by 2020 (Statista 2019). It is one of the rapid growing markets (Hassali, 2015). Globally, Asia Pacific makes up the largest share of the beauty and personal market, accounting for around $32 \%$ of sales worldwide (Statista, 2019). The prestige cosmetics segment in Malaysia has reached USD 198 million in 2019 with expected yearly growth of 5\% (Statista 2019). Due to the growing demand of customers, many established Asian brands, such as Laneige, Etude House, and Innisfree from Korea have been rapidly expanding popularity among younger consumers. The top two Korean beauty products brands in Malaysia are Laneige and Innisfree followed by Sulwhasoo, Mamonde and Etude House (The Star 2019).

Hong and Kim (2013) discovered that Korean culture also known as "Korean Wave" has become popular and penetrated both East and Southeast Asia, including Malaysia, China, Singapore, Japan and Taiwan. Cho (2010) studied that South Korean films and TV dramas created the Korean Wave, which have impacted the rise of greater interest in Korea among Malaysians. In addition, many big cosmetics firms such as AMOREPACIFIC, LG Household $\&$ Healthcare and MISSHA have gained advantage of the Korean Wave and actively engaged with popular Korean artists as ambassadors to promote their beauty products (Cok, 2015). The Korean Wave has directly changed Malaysian lifestyle, way of thinking, aesthetics views, consumption patterns and consumption of Korean cultural products (Hong and Kim, 2013). Cho (2010) investigated that the customer perception of Korean wave has created by Korean products like beauty products, foods, K-pop, entertainment and smartphones. Herman, Widiasari and Hartono (2016) said that the popularity of K-pop and TV dramas has increased recognition and gained interest of the public towards Korean products. The famous Korean TV dramas such as "Descendants of The Sun" and "Globlin" have generated more attention and awareness of Korean products. For example, a popular female actor applying Korean brand lipstick in the scenes of the TV dramas. This kind of advertising tactics facilitates the K-drama fans intention to purchase the particular beauty product endorsed by their favor artists. Young adults are strong influencers and use brands to become trendsetters and opinion leaders for particular groups of society (Azuizkulov, 2013). The young consumers tend to 
pick up the trend and follow the recent fashion of the popular artists. Leslie, Sparling and Owen (2001) examined that young consumers act as a change agent to influence the culture and society. They are willing to explore and seek latest trend due to impact of K-pop and K-drama that stimulate interests among them towards Korean products. According to The Economic Times (2018), the massive advent of Korean Wave has influenced the younger generation to be more inclined to purchase the Korean branded beauty products through the advert from K-drama and K-pop. According to Effendi's (2012) investigation on young adults who are familiar with K-pop, it shows that the Korean fashion and lifestyle lead them to imitate the icon of K-pop, characters of TV dramas or the famous song - Gangnam Style. For instance, they would like to follow the Korean Wave's trend of music, makeup, hairstyle, clothing, etc. This happened because popular artists have impacted young consumers on perception of Korean products.

As this phenomenon has stimulated many Korean beauty products to penetrate into Malaysian consumer markets, it would have significant influence on undergraduate students. They are at a young age where they are very much concerned about self-appearance and self-attractiveness, which are important components of individuals' self-concepts and these affect the way they are perceived and treated by others. Many beauty firms are more likely to target young consumers aged between 18 to 27 years as potential group of consumers (Azuizkulov, 2013) as this segment has increasingly strong purchasing power in the future that contributes to the revenue of beauty products. Azuizkulov (2013) stressed that undergraduate students are strong influencer, trendsetters and opinion leaders for particular groups of society for certain brands. Hence, it is important for beauty firms that are targeting undergraduate students to understand and determine their motivations that influence their purchase intention towards beauty products.

Despite the impact of K-wave, the studies on this phenomenon are relatively scarce. So far researchers have focused on examining Korean wave based on consumer behavior studies such as repurchase intention (Moslehpour, Wong, Pham \& Aulia, 2016), brand attitude (Kim, Han, Kim \& Paramita, 2013), and brand identity and perceived quality (Herman, Widiasari \& Hartono, 2016). In addition, previous researchers have examined consumer behavior on beauty products based on Theory of Reasoned Action (TRA) (Sukato \& Elsey, 2009), Theory of Planned Behavior (TPB) (Hsu, Chang \& Yansritakul, 2017) and brand loyalty (Hamza, 2011), but there are still limited studies conducted to explain total consumption of values based on K-wave phenomenon, particularly in Malaysian perspectives holistically. Therefore, Theory of Consumption Value (TCV) is used in this research in order to examine consumer values influencing purchase decision behavior towards Korean beauty products. There are five fundamentals of consumption values developed by Sheth, Norman and Gross (1991) to investigate consumers' choosing behavior and they are functional, social, emotional, conditional and epistemic.

The paper next discusses the Korean beauty industry, Theory of Consumption Value (TCV) as grounding theory and hypothesis development. Then research design and data analysis and discussion. 


\section{Korean Beauty Industry}

Korean Beauty products can be defined as Korean plastics surgery and Korean cosmetic products including makeup and skin care (Wen, 2014). In this research, Korean cosmetic products will only be used to examine the factors influencing undergraduate students purchase intention. In the late 1990s, Korea's popular culture also known as Korean Wave had successfully hit the shores of Southeast Asian countries with great force. Hong and Kim (2013) discovered that Korean Wave has become popular and penetrated among East and Southeast Asia and even Muslim nations, including Malaysia, Indonesia, Singapore, Japan and Taiwan. In 2011, Korean cosmetic products generated a revenue of $\$ 2,186,617$ and increased by $46 \%$ to $\$ 5,592,047$ in 2015 , while Korean makeup and skin care preparation increased by $10 \%$ from $\$ 26,441,774$ to $\$ 35,869,939$ in Malaysia which indicating that this industry has significant potential growth in profit margin (International Trade Administration, 2016). This report indicates that the increasing sales of Korean beauty products is a popular trend and becoming an important industry in Malaysia.

The boom of Korean beauty culture rises from Korean TV dramas such as Winter Sonata, which serves as the pioneer of Korean cultural goods. Cho's (2010) study on South Korean films and TV dramas revealed that Korean Wave created a greater influence in Malaysia than in Korea as many K-dramas are being aired during prime-time on TV2 and 8TV, and 4 Korean channels on the paid satellite Astro. The famous artists have always been recognized as beautiful and fair-skinned by publics and managed to capture audiences' attention with their good looks. Hence, the audiences and fans of the celebrities are influenced to try cosmetic products that are made in Korea. This wave has led Malaysians to take greater curiosity in Korean cultures and merchandises, such as cosmetics, skin care, traditional costume, language and "kimchi" (Cho, 2010). The Korean Wave has directly changed Malaysians' lifestyles, ways of thinking, aesthetics views, consumption patterns and consumptions of Korean cultural products such as Korean pop music, smartphones, cosmetics and foods (Cho, 2010).

In addition, the price range for Korean cosmetics, skin care and other personal care products that are available in Malaysia has a greater advantage as the prices are more affordable by the consumers' as compared with products from other countries, such as Japan, the United States, Europe and Australia. Korean beauty brands, such as Laneige, The Face Shop and Innisfree are actively opening boutique outlets and department stores in Malaysia. The well-known brand outlets aggressively invest in marketing activities in order to increase their market shares in domestic cosmetics industry. Swidi, Cheng, Hassan, Al-Hosam and Mohammad Kassim (2011) examined that there are many well-known imported Western and Asian beauty product brands sold in large number at local grocery retailers and leading pharmacy chains. Those brands included Loreal, Bobby Brown, SK-II, Shu Uemura, Hada Labo, Maybelline and Silky Girl. Customers are having more options in this competitive market to buy their favorite brands. They are expecting more innovative products from the beauty firms. Thus, it is important for beauty firms to have better understanding of the customers' preferences as well as putting more effort in research and development activities in order to enhance the brand awareness and brand loyalty among the existing and potential customer groups. 


\section{Theory of Consumption Value}

The Theory of Consumption Value (TCV) also known as The Theory of Market Choice Behavior (TMCB) has been developed and used to assess in various studies by Sheth, Newman and Gross (1991). It identifies why consumers make the choices they make. TCV is a conceptual framework to explain customer evaluation on products or services (Lin and Huang 2012). TCV identifies the significant values that customers perceived and provide a better understanding on consumer choice behavior. It has been applied in a wide range of products to examine customer purchase and choice behavior (Sheth, Newman \& Gross, 1991), including sustainability consumption (Lee, Levy \& Yap 2015) and biofuels consumption (Zailani, Iranmanesh, Hyun \& Ali 2019). Furthermore, it has been applied in previous researches to determine consumer behavior towards personal care and the theory validity has been proven reliable (Candan, Unal \& Ercis, 2013). In this study, TCV functional value, social values and epistemic values are used to investigate undergraduate students purchase intention towards Korean beauty products in Malaysia.

\section{Functional Values}

Functional value refers to benefit perceived by consumers through the product functional, utilitarian and physical performance of situation (Sheth et al. 1991). It indicates consumer preferences affected by product physical and practical factors such as performance, reliability, and product's price (Xiao and Kim, 2009) and individual perception of benefits in buying a product (Park and Rabolt 2009). Brands are using functional benefits such as lower cost, quality, products superior performance, price or better owing's value (Doyle and Stern 2006). In measuring the functional value, some studies referred to it as monetary value (Noypayak, 2009; (Awuni \& Du, 2016 \& Burcu \& Seda, 2013) while some referred to it as convenient value (Omigie, Zo, Rho \& Ciganek, 2016; Pihlstrom \& Brush, 2008), and quality value (Zeithaml, 1988; Zhao, 2014), such as product performance and reliability (Xiao \& Kim, 2009).

Rahnama's (2017) study on consumer choice towards organic yogurt, functional value of price has the greatest influence on purchase preference. Several studies supported that price is the key determinant that greatly influence consumer choice behavior and reasonable pricing stimulates them to make purchase on organic yogurt ( Mann Ferjani, \& Reissig 2012). Ong et al. (2010) examined that Malaysian consumers are less likely to focus on price as they always perceived high price -value of the product provides a better performance or benefit. Hassali et al. (2015) investigated that customers are willing to pay higher price based on good benefits and high quality cosmetic goods such as anti-aging, whitening and multi-functions. On the other hand, Lee Graefe \& Hwang's (2012) study indicated that customers are willing to continue to purchase the product again when they feel the price of the product is fair and reasonable.

In quality-value perspective, customers perceived beauty products' benefits as healthy skin and good appearance. Females and males with good appearances are attractive and have good performance reviews at work. It indicates that the use of beauty products can boost a person's self-image and self-esteem and making them more attractive and appealing 
(Wicklund \& Gollwitzer 1982). Eze et al (2012) contended that the product quality is the strongest predictor to stimulate purchase intention on cosmetic products. With reference to existing literature, in this research, functional value towards Korean beauty products is described as the undergraduate students' perceptions of product are to obtain maximum benefit at low price with good quality and this perception impacts their purchase decision.

The effect of functional value on consumer behavior and purchase intention can be found in past researches, for example, consumer choice behavior (Sheth dt al 1991; Rahnama, 2017), satisfaction and loyalty (Hassan, 2017), and purchase intention (Awuni \& Du 2016). Hence, it is assumed that purchase intention on Korean beauty product is higher when the product provides good performance and economic value. Therefore, hypothesis 1 is proposed as follow:

H1: Functional value has a positive impact on undergraduate students' purchase intention towards Korean beauty products.

\section{Social Values}

Social values can be described as the benefit that is perceived and acquired in alternative association to one or several social groups (Sheth at al., 1991). It refers to a product possess symbolic or conspicuous consumption value which means an individual purchases a particular brand or product to acquire a unique or prestige status and image (Candan, Unal \& Ercis, 2013). These benefits or prestigious images can be influenced by social surroundings, reference groups and opinions leaders. This is particular relevant in Korean beauty products as consumers are influenced by the K-wave players such as beauty of actresses that emits fair and flawless face. Reference group plays a key role in social value and it can be defined as the individuals with whom the person compares according to personal values, behaviors and attitudes (Schiffman \& Kanuk, 1997). Besides, opinion leaders are highly effective elements in convincing consumer purchase intention as they practice interpersonal communication and social interaction by word-of-mouth (Sheth et al., 1991). Therefore, reference group, friends and social status do influence individuals' selection of beauty products and strengthen individuals' intention to purchase Korean beauty products in order to fit in their own social group effectively. Students may have motive to purchase beauty products with favorable status when the beauty brand carries a meaningful message as they believe that others view them as having prestige images. Candan, Unal \& Ercis (2013) claimed that social values have positively influence young consumers' consumption because they are highly concerned about the symbolic value of the brand or product whether it can communicate to the social environments to provide prestige if they purchase that particular brand of personal care goods. Thus, it can be said that social value does have impact on youth purchase intention towards beauty products.

Several studies have shown that social value is related with symbolic benefits towards green products and beauty products (Rahnama, 2017; Awuni \& Du, 2016; Zhao, 2014; Candan, Unal \& Ercis, 2013). Therefore, this study proposed the socially approved and prestige image view from others that will influence undergraduate students' purchase intention on Korean beauty products. The hypothesis 2 is proposed as follow: 
H2: Social value has a positive impact on undergraduate students' purchase intention towards Korean beauty products.

\section{Epistemic Values}

Epistemic value refers to perceived utilitarian of an alternative product that is able to satisfy consumers' curiosity, provides novelty and knowledge (Sheth, 1991). Epistemic value occurs when consumers purchase alternative products as a result of perceiving their previous consumed goods as bored; they are curious or have a desire to learn ( Sheth 1991; Yeo, Rozita, Naina and Mazzini 2015). This could be due to the fact that a consumer purchases alternative products that are able to deliver satisfaction of something new or fashionable or unique (Yeo et al 2015). Schiffman and Kanuk (1997) supports the fact that consumers are interested in looking for a variety of trendy and innovative products especially technological products. It indicates that this value established for the purchase motive is due to consumer seeking variety of "innovativeness" found in products. Basically, consumers are not loyal to a specific brand as they probably search for variety and novelty as well as prefer to try new products of different brands. Switching one brand to another is a very routine behavior for customers who prefer to use new goods (Sheth et al., 1991; Schiffman \& Kanuk, 1997).

Candan, Unal and Ercis (2013) examined that some customers have the tendency to prefer new products whilst some others may follow the "innovators" purchase preferences and their acceptance and adaptation is not fast. Hence, innovative consumption behavior may drive undergraduate students purchase intention towards Korean beauty products. Their study also stressed that epistemic value has the greatest impact on the purchase intention towards personal care products. Other studies supported that epistemic value has significantly influenced behavioral intention, such as convergence home robots purchase intention (Hur, Yoo \& Chung, 2011), intention to purchase through the Internet (Cheng, Wang, Lin \& Vivek, 2007) and global brand image purchase intention (Park \& Rabolt, 2009). Therefore, current study considers epistemic values as one of the significant variables to predict the undergraduate students' purchase intention towards Korean beauty products. Therefore, epistemic is being referred as novelty seeking motive consumption on Korean beauty products. Hence hypothesis 3 is proposed as follow:

H3: Epistemic value has a positive impact on undergraduate students' purchase intention towards Korean beauty products.

\section{Intention to purchase Korean beauty products}

Purchase intention refers to a person's intention or motive to purchase a specific product or service which the individual has selected for himself or herself after a confident evaluation (Laroche \& Sadokierski, 1994; Laroche et al., 1996; MacKenzie et al., 1986). Intention to purchase beauty products can be defined as the consideration to make buying decision on beauty products. Yang, Huang and Feng (2011) observed that a rising number of female undergraduate students has started to exhibit high interest in enhancing their appearance by wearing makeup. Consumers have been significantly influenced by Korean culture that leads them to follow Korean lifestyle that involves the purchasing of Korean cosmetics (Cho, 2010). 
It indicates that beauty products are started to become a daily necessity for undergraduate students. When a person has paid intention to Korean beauty product, the acceptance of the person towards Korean beauty products will be higher.

In this study, the intention to purchase Korean beauty product is the dependent variable, which will be impacted by other independent variables, including functional, social, and epistemic.

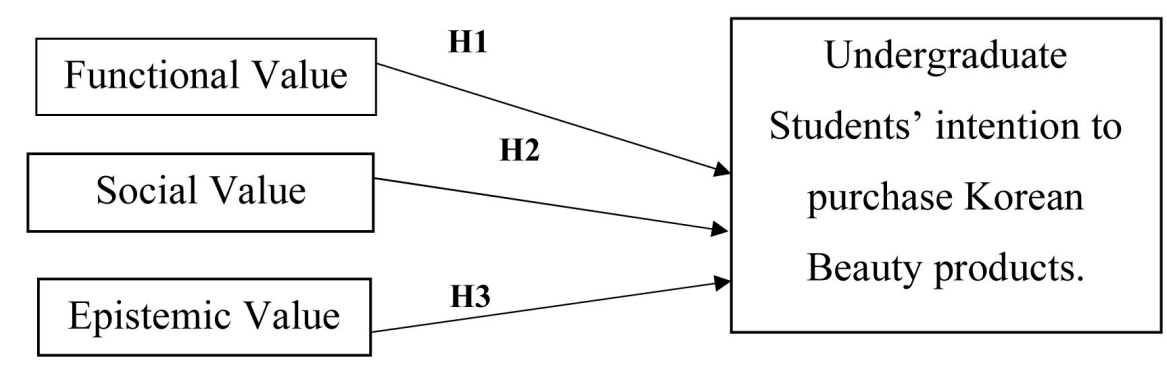

Figure 1. Research model

\section{Methodology and Data Analysis}

The study employed a quantitative research that was able to investigate the relationship among measured variables and represent that relationship in numerical form through the use of statistical analysis (Creswell, 2013). Hence questionnaire in the form of survey was conducted. A total of 380 questionnaires were distributed to undergraduates aged between 18 and 26 in Klang Valley using convenient sampling in July till September 2017.A total of 351 questionnaires are usable. They were $236(67.2 \%)$ female undergraduate respondents and $115(32.8 \%)$ male undergraduate respondents aged between 18 to 26 and most of the respondents aged around 21 to $23(49.6 \%)$ while $128(36.5 \%)$ of them aged between 18 to 20 years old and $49(13.9 \%)$ respondents aged between 24 to $26.50 .1 \%$ of them have an income below RM500 and 7.7\% has an income above RM 2000.

This study adopted the seven-point Likert scale to obtain higher variance in order to accomplish greater scale reliability. The respondents rate the items on a scale from 1 (strongly disagree) to 7 (strongly agree). All measurement items were all adapted from previous studies. For instance, functional value 8 items and epistemic value 4 items were adapted from Rahnama (2017). Social values 10 items were adapted from Awuni \& Du (2016) and Candan, Unal \& Ercis (2013) and 3 items purchase intention were adapted from Iyer, Davari \& Paswan (2016). A pilot test was conducted prior to the main data collection to determine the reliability and any unclear meaning of items. The pilot test revealed that the scales are having adequate reliable from 0.874 to 0.926 for all variables.

SmartPLS was used to conduct the main data analysis in accordance to Hair, Hult, Ringle and Sarstedt (2017). The data analysis started with a measurement model and followed by a structural model. Assessments on measurement model consists of internal consistency reliability, followed by convergent validity and validity of discriminant.

Firstly, internal consistency was assessed by examining the composite reliability (CR). CR 


\section{Macrothink}

Journal of Management Research

ISSN 1941-899X

2020, Vol. 12, No. 3

value above 0.6 to 0.7 are considered acceptable and 0.7 to 0.9 are considered satisfactory ( Hair et al 2017). As shown in Table 2, CR values are above 0.7. Hence, the measurement items are reliable and proceeded to convergent validity.

Convergent validity refers to degree of a measure correlates positively with alternative measuring items of the same variable (Hair et al 2017). To examine the convergent validity, outer loadings and the average variance extracted (AVE) were being assessed. AVE is the square of a measurement item outer loading indicate the degree of variation in an item is explained by a variable (Hair et al 2013;2017). Hence, outer loadings of 0.708 and AVE of 0.5 are considered acceptable for convergent validity. As shown in table 1, all outer loadings are above 0.708 and AVE of all constructs are well above 0.5 . Hence, convergent validity is established and followed by analyzing discriminate validity. 


\section{Macrothink \\ Journal of Management Research \\ ISSN 1941-899X \\ 2020, Vol. 12, No. 3}

Table 1. Results of Measurement Model ( $n=351)$

\begin{tabular}{|c|c|c|c|c|c|}
\hline Construct & Items & $\begin{array}{l}\text { Outer } \\
\text { Loading }\end{array}$ & $\begin{array}{l}\text { Average } \\
\text { Variance } \\
\text { Extracted }\end{array}$ & $\begin{array}{l}\text { Composition } \\
\text { Reliability }\end{array}$ & $\begin{array}{l}\text { Cronbach's } \\
\text { Alpha }\end{array}$ \\
\hline $\begin{array}{l}\text { Functional } \\
\text { Value }\end{array}$ & $\begin{array}{l}\text { FV_1 } \\
\text { FV_2 } \\
\text { FV_3 } \\
\text { FV_4 } \\
\text { FV_5 } \\
\text { FV_6 } \\
\text { FV_7 } \\
\text { FV_8 }\end{array}$ & $\begin{array}{l}0.737 \\
0.810 \\
0.788 \\
0.819 \\
0.656 \\
0.800 \\
0.856 \\
0.646\end{array}$ & 0.589 & 0.919 & 0.899 \\
\hline $\begin{array}{l}\text { Social } \\
\text { Value }\end{array}$ & 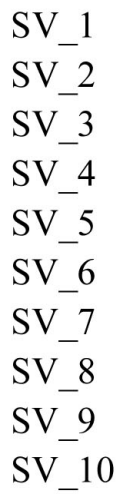 & $\begin{array}{l}0.748 \\
0.783 \\
0.815 \\
0.795 \\
0.770 \\
0.618 \\
0.660 \\
0.587 \\
0.732 \\
0.735\end{array}$ & 0.530 & 0.918 & 0.900 \\
\hline $\begin{array}{l}\text { Epistemic } \\
\text { Value }\end{array}$ & $\begin{array}{l}E V \_1 \\
E V \_2 \\
E V \_3 \\
E V \_4\end{array}$ & $\begin{array}{l}0.844 \\
0.882 \\
0.784 \\
0.662\end{array}$ & 0.636 & 0.874 & 0.809 \\
\hline $\begin{array}{l}\text { Purchase } \\
\text { Intention }\end{array}$ & $\begin{array}{l}\text { PI_1 } \\
\text { PI_2 } \\
\text { PI_3 }\end{array}$ & $\begin{array}{l}0.906 \\
0.875 \\
0.840\end{array}$ & 0.764 & 0.907 & 0.846 \\
\hline
\end{tabular}

Discriminant validity can be referred as the degree to which a construct is significantly different from another construct through empirical criterions (Hair et al., 2014). In other words, discriminant validity is to make sure that the construct is distinct, unique and captures phenomenon not exhibited between other constructs in the model. Heterotrait-monotraits ration (HTMT) was is more appropriate to evaluate constructs discriminant validity. An HITMT criterion value above 0.9 and a confidence internal containing 1 suggest construct lacking discriminate validity (Hair eta 12017 ; Henseler et al 2015). Table 2 indicates that the constructs are having adequate discriminate validity and proceed to assess structural model. 
Table 2. HTMT Criterion $(\mathrm{n}=351)$

\begin{tabular}{|l|l|l|l|}
\hline & FV & SV & EV \\
\hline SV & $\begin{array}{l}0.493 \\
(0.393 ; 0.587)\end{array}$ & & \\
\hline EV & $\begin{array}{l}0.502 \\
(0.400 ; 0.601)\end{array}$ & $\begin{array}{l}0.603 \\
(0.492 ; 0 / 692)\end{array}$ & \\
\hline PI & 0.640 & 0.725 & 0.730 \\
$(0.542 ; 0.718)$ & $(0.648 ; 0.787)$ & $(0.638 ; 0.813)$ \\
\hline
\end{tabular}

Note: $\mathbf{F V}=$ Functional Value, $\mathbf{S V}=$ Social Value, $\mathbf{E V}=$ Epistemic Value, $\mathrm{PI}=$ Purchase Intention

Hypothesis testing were assessed through structural model. The structural model was generated through the bootstrapping process. There is setting 5000 as the subsamples for the 351 surveys. The results of the structural model analysis shown in figure 2. The structural model was first assessed collinearity issues by checking the inner VIF values of predictor constructs as shown in table 3 . All VIFs values are below 5 , indicating collinearity issues is not critical in the model ( Hair et al 2017).

Table 3. collinearity Assessment $(n=351)$

\begin{tabular}{lc}
\hline Construct & Purchase Intention (VIF) \\
\hline Epistemic value (EV) & 1.487 \\
Social value (SV) & 1.554 \\
Functional value (FV) & 1.347 \\
\hline
\end{tabular}




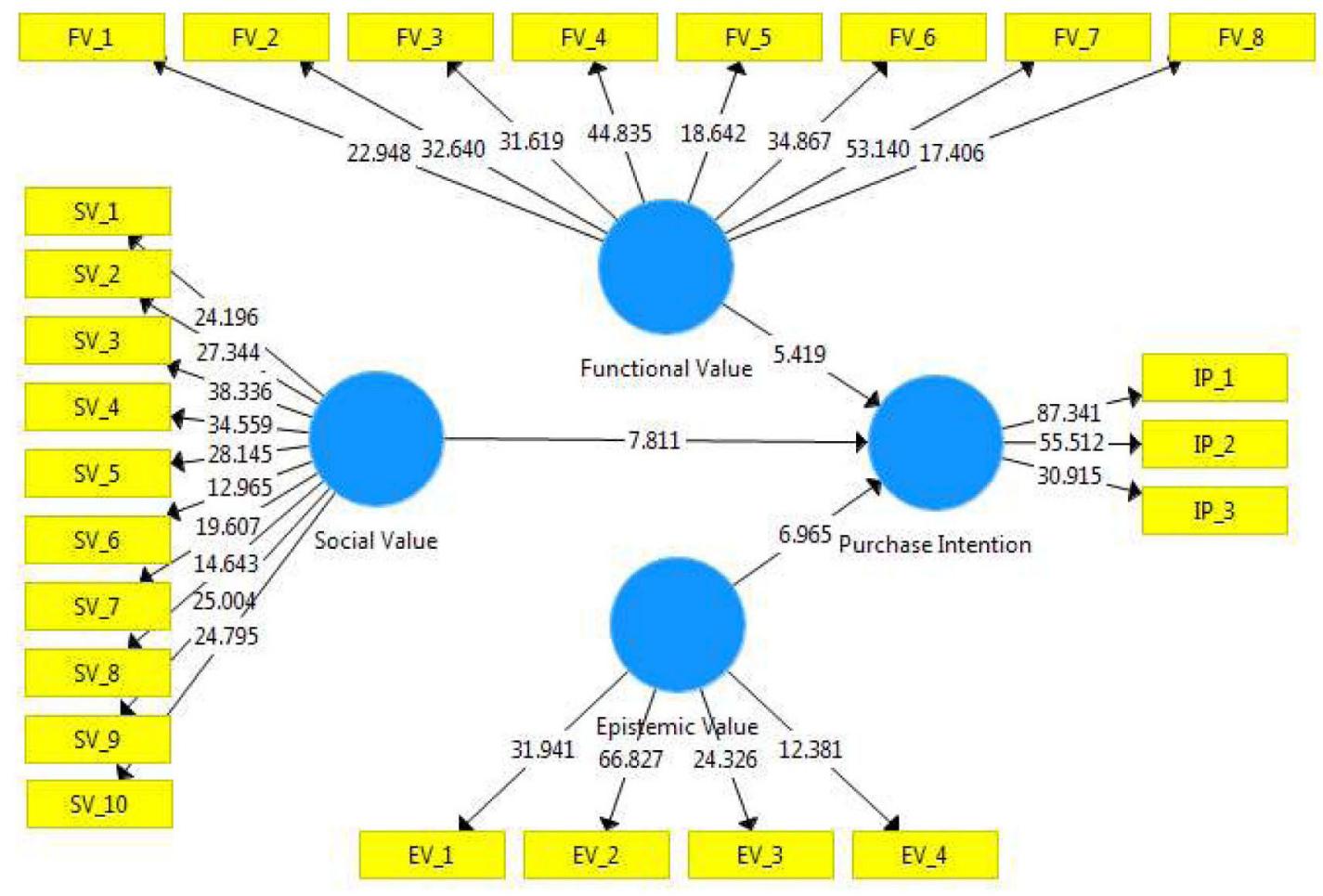

Figure 2. Results of Structural Model ( $\mathrm{n}=351$, bootstrapping subsample=5000)

The path coefficient illustrates the hypothesized relationships between the constructs for the structural model as well as its significance is referred to standard errors. (Hair, Hult, Ringle \& Sarstedt, 2014). There are ranges from -1 to +1 and the nearer the coefficients are to 0 , the weaker the relationships indicates not significant. When path coefficient occurs closer to +1 or -1 shows either positive or negative strong relationship between construct which indicates path coefficient is significant. The bootstrapping process run through 5000 subsamples on 351 cases for establishing empirical $t$-values or $t$-values. The empirical $t$-values have greater than critical value if the path coefficient of relationship is significant. The critical values for one-tailed test included 1.645 (significance level $=5 \%$ ), 2.326 ( 3.09 (significance level $=0.1 \%$ ). From table 5.6 exhibits that hypothesis testing and t-values for the model. Hypothesis H1, H2 and H3 with their respective t-value of 6.965, 5.419 and 1.955 are all supported. Thus, the coefficient of determination was tested in following section. 
Table 4. Results of Hypothesis Testing $(n=351)$

\begin{tabular}{lcrrrrrl}
\hline & & \multicolumn{1}{c}{ Sample } & \multicolumn{1}{c}{ Std } & & & & \\
& Hypothesis & \multicolumn{1}{c}{ Mean } & Deviation & t-value & p-value & Decision & \multicolumn{1}{l}{$\mathrm{f}^{2}$} \\
\hline H1 & FV--> PI & 0.318 & 0.045 & 6.965 & 0.000 & Supported & 0.123 \\
H2 & SV-->PI & 0.264 & 0.048 & 5.419 & 0.000 & Supported & 0.209 \\
H3 & EV--> PI & 0.365 & 0.047 & 7.811 & 0.000 & Supported & 0.160 \\
\hline
\end{tabular}

Note: $\mathrm{p}<.05^{*}, \mathrm{p}<.01^{* *}, \mathrm{p}<.001 * * *$

Note: $\mathrm{FV}=$ Functional Value, $\mathrm{SV}=$ Social Value, EV=Epistemic Value, $\mathrm{PI}=$ Purchase Intention

The coefficient of determination symbolized as $\mathrm{R}^{2}$, can be explained as examine the proportion of a dependent variable of variance which is described through the independent variables associated to it (Hair, Hult, Ringle \& Sarstedt, 2014). Tenenhaus, Vinzi, Chatelin and Lauro (2005) emphasized that the $\mathrm{R}^{2}$ value of dependent variable should be sufficient for the purpose of accomplish the explanatory power at minimum level. The $\mathrm{R}^{2}$ should be adequate if it is encounter to equal or greater than 0.1 (Falk \& Miller, 1992). There is a rule for $\mathrm{R}^{2}$ that is dependent variables with $\mathrm{R}^{2}$ values of $0.25,0.50$ or 0.75 can be represented as week, moderate or substantial. Dependent variable for current study is purchase intention and value of $\mathrm{R}^{2}$ is 0.585 . This indicates that all independent variables (functional value, social value and epistemic value) can explain 58.5 of the variance in purchase intention. Hence, the model has a moderate level of predictive accuracy in this study. The effect size of each constructs was assessed. Effect size of 0.02, 0.15 and 0.35 are considered small, medium and large respectively (Hair et al 2014; 2017). From the table 4, effect size can be considered medium for social value and epistemic value and small for functional value.

The importance-performance map analysis (IPMA) as shown in Figure 3 and Table 5 indicated the IPMA of purchase intention reveals that both social value and functional value variables, are the important constructs as compared to the epistemic value construct.

The functional value already in highest performance, but social value is the lowest performance of 48.700. On the other hand, the significance of social value with a total effect of 0.398 is particularly high among the three variables. Therefore, increasing the performance of social value by one unit would increase the performance of the purchase intention (PI) by 0.398 points from 48.700 (Figure 3) to 49.098 . 


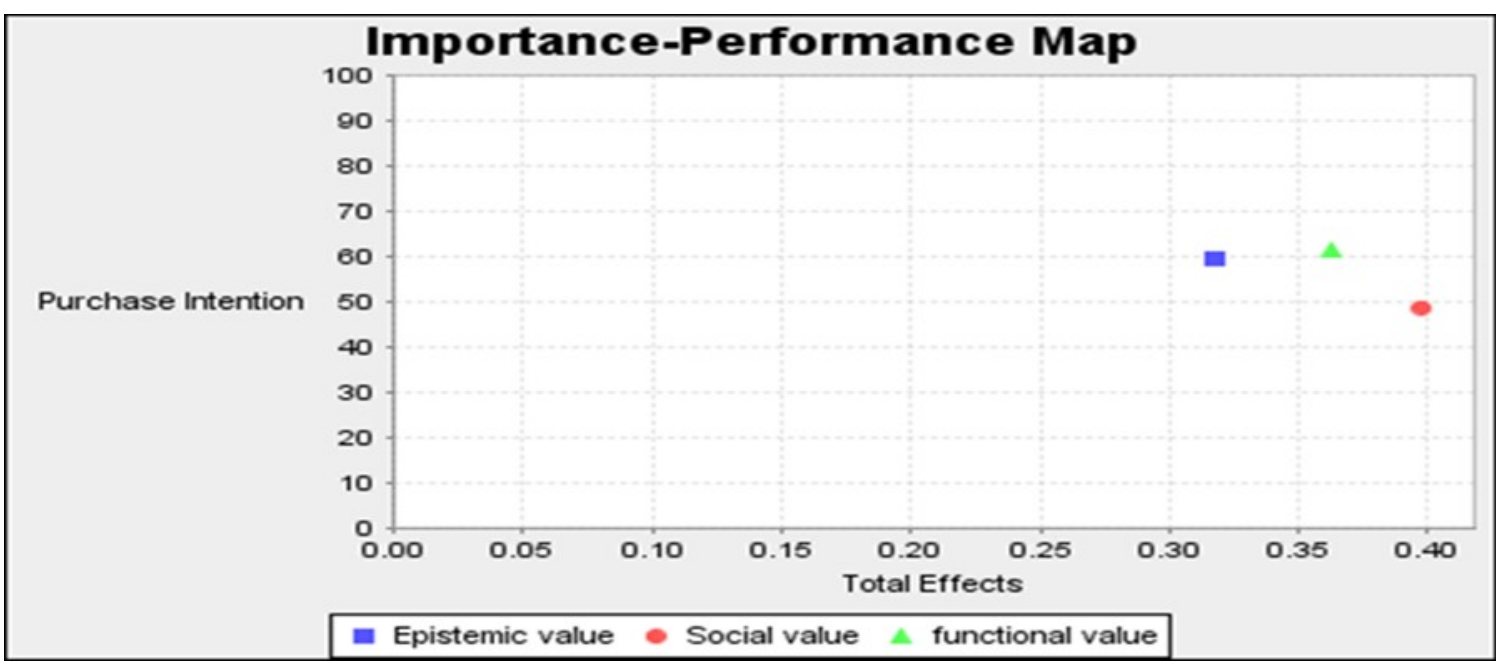

Figure 3. IPMA Analysis

Table 5. IPMA Result

\begin{tabular}{lll}
\hline Construct & Importance (Total Effect) & Performance (Index Value) \\
\hline Epistemic Value & 0.318 & 59.300 \\
Social Value & 0.398 & 48.700 \\
Functional Value & 0.363 & 61.361
\end{tabular}

\section{Discussion}

The primarily purpose of this research is to examine the factors influencing undergraduate students purchase intention towards Korean beauty products. This research employed TCV that included functional value, social value and epistemic value to examine Malaysian undergraduate purchase intention towards Korea brand beauty products. From the structural analysis, all 3 variables are found to be significantly influencing the purchase intention of Korean beauty products. H1 supported the consistency with previous studies such as Rahnama's (2017). As for H2, the finding is consistent with (Rahnama, 2017), (Awuni \& Du, 2016), (Zhao, 2014) and (Candan, Unal \& Ercis, 2013) findings in resulting that Social Value does play an important role in the people's behavioral intention as well as acceptance towards Korean beauty products. H3 is supported and is consistent with previous studies such as Hur, Yoo \& Chung (2011), Cheng, Wang, Lin \& Vivek (2007) and Park \& Rabolt's (2009) findings that Epistemic Value does play an important role in the consumer's behavioral intention in Korean beauty products. The model explains that almost $60 \%$ of the variance in purchase intention with social values has the highest effect. Besides, IPMA of purchase intention reveals that both social value and functional value variables are the important constructs as compared to the epistemic value construct. The findings of the current research can make a significant contribution to Theory of Consumption value that social, functional and Epistemic values indeed have impact on young consumers' choice of skin care products. 


\section{Mll Macrothink}

Journal of Management Research

ISSN 1941-899X

2020, Vol. 12, No. 3

The results of this study suggested that undergraduate students possess higher motivation to purchase Korean beauty products if the products provide consistence quality and reasonable price. On the other hand, social value explains that if the students' perceived persons are important to them as advisers as well as the brand is able to communicate social approval, the possibility of leading them to buy Korean beauty products is higher. Furthermore, the students can easily access to knowledge about skin care and cosmetics and are motivated to look for information related to Korean products; thence the undergraduate students' intention to buy Korean beauty products is possibly increased.

Therefore, marketers' efforts in enhancing the performance of the purchase intention should be paramount in order to improve the performance of the social value as this construct has the highest importance, but relatively low performance, while functional and epistemic are the second and third priorities. There is a great need for improvement, which makes these aspects on which this structure is based on particularly relevant to management and marketing policy measures. This theme promotes and enhances social value appreciated by the users since the forecast for the purchase intention is quite high in performance. Therefore, managers/marketers should not focus too much on epistemic value of the product/services, as this may overwhelm the business if the purchase intention of consumers is affected.

\section{Limitation and Recommendations}

There are numerous limitations found in this study which need to be overcome for future studies. First, the sample of current research is Malaysian students who are of the ages of 18 to 26; therefore, the findings of this study could not be generalized in other samples. Moreover, this study only used three variables which resulted in significance to predict the purchase intention towards Korean beauty products of this specific sample group, but better generalizability with other samples could be provided by further studies.

The model proposed in current research has illustrated $58.5 \%$ of variance of undergraduate students' intention to purchase Korean beauty products. This indicates that the rest of the variance has not been described. Therefore, the variables utilized in the study might not be good enough to represent undergraduate students' intention to purchase towards Korean beauty products in Malaysia. There are two variables in TCV which are Emotional Value and Conditional Value that were not used in this research; these variables could be used to explain the $41.5 \%$ of variance of undergraduate students' intention to purchase Korean beauty products and increase the model explanatory power. Hence, the future empirical studies are encouraged to consider other issues like celebrity endorsement influence to purchase Korean goods as well as study on a wider scope such as Theory of Planned Behavior, Culture Influence, Branding and Priming Theory to provide greater extent of research.

\section{Conclusion}

The main objective of the current study is to examine the factors influencing undergraduate students' intention to purchase towards Korean beauty products in Malaysia. Three key factors have been chosen as the constructs to be predicted and analyzed in this study and they are functional value, social value and epistemic value. The findings have shown that all 


\section{NInscrothink}

Journal of Management Research

ISSN 1941-899X

2020, Vol. 12, No. 3

factors (Functional Value, Social Value and Epistemic Value) have a significant influence on undergraduate students purchase intention towards Korean beauty products. In brief, current research has given the basis for further examination on the field of purchase intention towards Korean beauty products. This study has presented a general idea regarding consumers' behavioral intention towards Korean beauty products to other researchers in terms of generating a new model. Moreover, this research enhanced the understanding on undergraduate students purchase intention towards Korean beauty products that can benefit the cosmetics industry, business investors and marketers in establishing appropriate and effective marketing plans to attract undergraduate students.

\section{Declaration of Conflicting Interest}

The authors declared the following potential conflicts of interest with respect to the research, authorship and/or publication of this article: The authors declare that there is no conflict of interest.

\section{Funding}

This work was supported by the HELP University Internal Research Grant Scheme (IRGS)(Project No: 20-02-007)

\section{References}

Awuni JA., \& Du J (2016) Sustainable consumption in Chinese cities: green purchasing intentions of young adults based on the theory of consumption values. Sustainable Development, 24(2), 124-135. https://doi.org/10.1002/sd.1613

Azuizkulov, D. (2013). Country of origin and brand loyalty on cosmetic products among Universiti Utara Malaysia students. Atlantic Review of Economics. 2. Retrieved from http://www.unagaliciamoderna.com/eawp/coldata/upload/cosmetic_products_malaysia.pdf

Burcu, C., \& Seda, Y. (2013). Investigating between Consumption Values and Personal Values of Green Product Buyers. International Journal of Economics and Management Sciences. 2(12), 4-40.

Candan, B., Unal, S., \& Ercis, A. (2013). Analysing the relationship between consumption values and brand loyalty of young people: A study on personal care products. European Journal of Research on Education. 29-46. Retrieved from http://iassr2.org/rs/010405.pdf

Cheng, J.M.S., Wang, E.S.T., Lin, J.Y.C., \& Vivek, SD. (2009). Why docustomers utilize the internet as a retailing platform?. Asia Pacific Journal of Marketing and Logistics, 21(1), 144 - 160: https://doi.org/10.1108/13555850910926290

Cho, C.H. (2010). Korean Wave in Malaysia and Changes of the Korea-Malaysia Relations. Malaysia Journal of Media Studies. 12(1), 1-14. Retrieved from http://vodppl.upm.edu.my/uploads/docs/kom3362_1328166233.pdf

Cok, M. (2015). Marketing Korean Cosmetic in Italy: Feasibility study of Market Entry. Retrieved from http://www.cek.ef.uni-lj.si/magister/cok2017-B.pdf 


\section{MInstitute ${ }^{\text {Macrothink }}$}

Journal of Management Research ISSN 1941-899X 2020, Vol. 12, No. 3

Doyle, P. and Stern, P. (2006). Marketing management and strategy. Edinburgh Gate, Harlow: Pearson Education.

Effendi, T. D. (2012). The Comparison of K-pop and J-pop Influences to University Students in Malang, East Java - Indonesia. Proceedings-Human Resource Development, Education, Morals, Ethics, and Politics-002 4 th International Conference on Humanities and Social Sciences. Retrieved from http://tar.thailis.or.th/bitstream/123456789/725/1/002.pdf

Eze, U.C, Tan, C.B and Yeo, L.Y. (2012). Purchasing cosmetic products: A preliminary perspective of Gen-Y. Contemporary management research, 8(1), 51-60. http://dx.doi.org/10.7903/cmr.10149

Falk R. F. \& Miller, N. B. (1992) A Primer for Soft Modeling. Akron, Ohio: The University of Akron Press.

Hair, J. F., Hult, G. T. M., Ringle, C. \& Sarstedt, M. (2013). A Primer on Partial Least Squares Structural Equation Modeling (PLS-SE). Sage Publications, Inc.

Hair, J. F., Hult, G. T. M., Ringle, C. \& Sarstedt, M. (2017). A Primer on Partial Least Squares Structural Equation Modeling (PLS-SE). (2 ${ }^{\text {nd }}$ Eds), Sage Publications, Inc. https://doi.org/10.15358/9783800653614

Hair, J.F., Hult, G.T.M., Ringle, C.M., \& Sarstedt, M. (2014). Partial least squares structural equation modeling (PLS-SEM): An emerging tool in business research, European Business Review, 26(2), 106-121. https://doi.org/10.1108/EBR-10-2013-0128

Hamza, S. K. (2011). The Influence of Brand Loyalty on Cosmetics Buying Behavior of UAE Female Consumers. International Journal of Marketing Studies. 3(2). https://doi.org/10.5539/ijms.v3n2p123

Hassan, Z. (2017). Impact of Social, Epistemic and Conditional Values on Customer Satisfaction and Loyalty in Automobile Industry: a Structural Equation Modelling. Journal of Marketing and Consumer Behaviour in Emerging Markets. 1(5). https://doi.org/10.7172/2449-6634.jmcbem.2017.1.3

Hassali, M.A., AL-Tamimi S.K., Dawood O.T., Verma A.K., \& Saleem F. (2015). Malaysian cosmetic market: current and future prospects. Pharmaceut Reg Affairs, 4(4). https://doi.org/10.4172/2167-7689.1000155

Henseler, J., Ringle, C. M., \& Sarstedt, M. (2015). A New Criterion for Assessing Discriminant Validity in Variance-based Structural Equation Modeling. Journal of the Academy of Marketing Science, 43(1), 115-135: https://doi.org/10.1007/s11747-014-0403-8

Herman, R. T., Widiasari, J., Lasmy \& Hartono, H. (2016). How Popular Culture Affects Brand Identity and Perceived Quality in Consumer Decision Making. Pertanika J. Soc. Sci \& Hum, 24, 9-18. 


\section{Al Macrothink}

Journal of Management Research

ISSN 1941-899X

2020, Vol. 12, No. 3

Hong, HS., \& Kim, CH. (2013). Surfing the Korean Wave. Qualitative Market Research, 16 (1), 53-75: https://doi.org/10.1108/13522751311289767

Hsu, C., Chang, C., \& Yansritakul, C. (2017). Exploring purchase intention of green skincare products using the theory of planned behavior: Testing the moderating effects of country of origin and price sensitivity. Journal of Retailing and Consumer Services, 34, 145-152. https://doi.org/10.1016/j.jretconser.2016.10.006

Hur, W. M., Yoo, J. J., \& Chung, T. L. (2011). The Consumption Values and Consumer Innovativeness on convergence products. Industrial Management \& Data Systems, 112(5), 688-706. https://doi.org/10.1108/02635571211232271

Iyer, P., Davari, A., \& Paswan, A. (2016). Green products: Altruism, economics, price fairness and purchase intention. Social Business, 6(1), 39-64: https://doi.org/10.1362/204440816X14636485174912

Kim, J., Han, W.H., Kim, D.T., \& Paramita, W. (2013). Is beauty in the eye of the beholder? Gender and beauty in the cosmetics sector: A comparative study of Indonesia and Korea. Marketing Intelligence \& Planning, 31(2), 127-140. https://doi.org/10.1108/02634501311312035

Laroche, M., \& Sadokierski, R.W. (1994). Role of Confidence in a Multi-brand Model of Intentions for a High Involvement Service. Journal of Business Research, 29, 1-12. https://doi.org/10.1016/0148-2963(94)90022-1

Laroche, M., Kim, C., \& Zhou, L. (1996). Brand Familiarity and Confidence as Determinants of Purchase Intention: An Empirical Test in a Multiple Brand Context. Journal of Business Research, 37, 115-120. https://doi.org/10.1016/0148-2963(96)00056-2

Lee, C.K.C., Levy, DS., \& Yap, C.S.F (2015),How does the theory of consumption values contribute to place identity and sustainable consumption? International Journal of Consumer Studies, 39. https://doi.org/10.1111/ijcs.12231

Lee, W.S., Graefe, A.R., \& Hwang, D. (2012). Willingness to pay for an ecological park experience. Asia Pacific Journal of Tourism Research, 8(3), 288-302: https://doi.org/10.1080/10941665.2011.652970

Leslie, E., Sparling, P. B., \& Owen. N. (2001). University Campus Settings and the Promotion of Physical Activity in Young Adults: Lessons from Research in Australia and the USA. Health and Education, 101(3). 116-125: https://doi.org/10.1108/09654280110387880

Lin, P.C. and Huang, Y.H. (2012). The influence factors on choice behavior regarding green products based on the theory of consumption values. Journal of Cleaner Production, 22(1), 11-18. https://doi.org/10.1016/j.jclepro.2011.10.002

Lockley, A. K., \& Bardsley, R. G. (2000). DNA-based methods for food authentication. Trends in Food Science and Technology, 11, 61-11. https://doi.org/10.1016/S0924-2244(00)00049-2 
Mann, S., Ferjani, A., \& Reissig, L. (2012). What matters to consumers of organic wine? British Food Journal, 114, 272-284. https://doi.org/10.1108/00070701211202430

McKinsey\& Company. (2012). The New Indonesian Consumer. Retrieved September 17, 2017:http://csi.mckinsey.com/knowledge_by_region/asia/rest_of_asia/new_indonesian_consu mer

Mitsui, T. (1996). New Cosmetic Science. Elsevier, Amsterdam - Lausanne - New York Oxford - Shannon - Singapore - Tokyo.

Moslehpour, M., Wong, W.K., Pham, K.V., \& Aulia,C.K. (2017). Repurchase intention of Korean beauty products among Taiwanese consumers. Asia Pacific Journal of Marketing and Logistics, 29(3), 569-588. https://doi.org/10.1108/APJML-06-2016-0106

Noypayak, W. (2009). Value Dimensions of Thailand as Perceived by U.K. Tourists, $R U$ International Journal. 3(1), 141-154.

Omigie, N, O., Zo, H., \& Rho, J. J. (2017). Customer pre-adoption choice behavior for M-PESA mobile financial services. Industrial Management \& Data Systems. 117(5), 510-926. https://doi.org/10.1108/IMDS-06-2016-0228

Ong, F. S., Kitchen, P. J., \& Chew, S. S. (2010). Marketing a Consumer Durable Brand in Malaysia: A Conjoint Analysis and Market Simulation. The Journal of Consumer Marketing, 27(6), 507-515. https://doi.org/10.1108/07363761011078244

Park, H. J., \& Rabolt, N. J. (2009). Culture Value, Consumption Value, and Global Brand Image: A Cross-National Study. Psychology \& marketing, 26(8), 714-735. https://doi.org/10.1002/mar.20296

Pihlström, M., \& Brush, G.J. (2008). Comparing the perceived value of information and entertainment mobile services. Psychology \& Marketing, 25(8), 732-755. https://doi.org/10.1002/mar.20236

Rahnama, H. (2016). Effect of Consumption Values on Women's Choice Behavior Toward Organic Foods: The Case of Organic Yogurt in Iran. Journal of Food Products Marketing, 23(2), 144-166. https://doi.org/10.1080/10454446.2017.1244790

Schiffman, LG., \& Kanuk. L.L. (1997). Consumer behavior. Upper Saddle River, N.J.: Prentice Hall.

Sheth, J., Newman, B. \& Gross, B. (1991). Consumption Values and Market Choices, Theory and Applications. South-Western Publishing Co. Cincinnati.

Statista (2019). Cosmetics market size in APAC 2015-2020. Retrieved from https:/www.statista.com/statistics/550547/cosmetic-market-size-asia-pacific/.

Souiden, N. \& Diagne, M. (2009). Canadian and French men's consumption of cosmetics: comparison of their attitudes and motivations. Journal of Consumer Marketing, 26(2), 97-109. https://doi.org/10.1108/07363760910940465 
Sukato, N., \& Elsey, B. (2009). A model of male consumer behaviour in buying skin care products in Thailand. ABAC Journal, 29(1), 39-52.

Swidi, A., Cheng, W., Hassan, M. G., Al-Hosam, A., \& Mohd Kassim, A. W. (2010) The mainstream cosmetics industry in Malaysia and the emergence, growth, and prospects of halal cosmetics. In: The Third International Conference on International Studies (ICIS 2010), 1st-2nd December 2010, Hotel Istana Kuala Lumpur. College of Law, Government and International Studies, Universiti Utara Malaysia. intok, pp. 1-20. ISBN 9789832078456

The Economic Times (2018). From K-pop to K-drama, Kimchi to K-beauty, Indian youngsters just can't get enough of Korea. Retrieved from https://economictimes.indiatimes.com/.

The Star (2019). Why has K-beauty grown to become such a huge craze?. Retrived from https://www.thestar.com.my/lifestyle/style/2019/07/18/k-beauty-hype-history. Feb 2020

Tenenhaus, M., Vinzi, V.E., Chatelin, Y. and Lauro, C. (2005) PLS Path Modeling. Computational Statistics \& Data Analysis, 48, 159-205: https://doi.org/10.1016/j.csda.2004.03.005

Statistics Canada. (2013). Probability sampling. Retrieved from https://www150.statcan.gc.ca/n1/edu/power-pouvoir/ch13/prob/5214899-eng.htm

Wen, Z. (2014). K-beauty, K-cafes, and K-Pop: The economic and social influence of transnational Korean culture in China. [Gyeonggi]World Congress of Korean Studies, 14. Retrieved from http://congress.aks.ac.kr/korean/files/2_1413767057.pdf

Wicklund, R.A., \& Gollwitzer, P.M. (1982). Symbolic Self-Completion, Hillsdale, NJ: Erlbaum

Xiao,G. Kim, J. O. (2009). The investigation of Chinese consumer values, consumption values, life satisfaction, and consumption behaviors Psychology \& marketing. Wiley Online Library. https://doi.org/10.1002/mar.20291

Yang, K. and L.D. Jolly, 2009. The effects of consumer perceived value and subjective norm on mobile data service adoption between American and Korean consumers. Journal of Retailing and Consumer Services, 16(6), 502-508. https://doi.org/10.1016/j.jretconser.2009.08.005

Yang, D. J., Huang, K. C., \& Feng, X. (2011), A Study of the Factors that Affect the Impulsive Cosmetics Buying of Female Consumers in Kaohsiung. International Journal of Business and Social Science, 2(24).

Yeo, B.L., Rozita, H., Naina, M., \& Mazzini, M. (2015). A Study of Malaysian Customers Purchase Motivation of Halal Cosmetics Retail Products: Examining Theory of Consumption Value and Customer Satisfaction. Procedia Economics and Finance, 37, 176-182. https://doi.org/10.1016/S2212-5671(16)30110-1

Zailani, S., Iranmanesh, M., Hyun, SS. \& Ali, Mohd. H. (2019). Applying the Theory of 


\section{Macrothink}

Journal of Management Research

ISSN 1941-899X 2020, Vol. 12, No. 3

Consumption Values to Explain Drivers' Willingness to Pay for Biofuels. Sustainability, 11. https://doi.org/10.3390/su11030668

Zeithaml, V. A. (1988). Consumer perceptions of price, quality, and value: a means-end model and synthesis of evidence. Journal of Marketing, 52(3), 2-22. https://doi.org/10.1177/002224298805200302

Zhao, X. (2014). Consumer Perceived Value of Salon Hair Coloring in China. Canadian Center of Science and Education. 6(6). https://doi.org/10.5539/ijms.v6n6p34 